\title{
Numerical investigation of the river-groundwater interaction characteristics in the downstream desert of the Heihe River, China
}

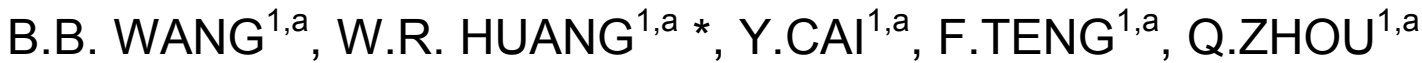 \\ ${ }^{1}$ Department of Hydraulic Engineering, Tongji University, Shanghai, China \\ a *Corresponding author: whuang77@@tongji.edu.cn
}

\begin{abstract}
KEYWORD: downstream desert; groundwater; river-groundwater interaction; evapotranspiration. ABSTRACT: The downstream is in the lower reaches of the Heihe River, northwestern China. The first step of the model development effort is to construct a groundwater flow model for the lower Heihe River. The software 'ModelMuse' is used to build and visualize the model for the downstream of Heihe River. A groundwater flow model was developed by MODFLOW-2005. The study area was simulated to research the river-groundwater interaction in the case of both evapotranspiration and no evapotranspiration, respectively. The results show that the river seeps into groundwater under the influence of evapotranspiration. The groundwater recharges the river without evapotranspiration.
\end{abstract}

\section{INTRODUCTION}

The Heihe River Basin is the second largest inland river, which supplies water for agricultural, industrial and ecological needs, locating in the semi-arid and arid region of northwest China, where groundwater plays a significant role in the water resources management. Many groundwater resources are limited and can not be reused on meaningful time scales for both human society and ecosystems. The predicted climate change will make these worse concerns in many parts of the world with the declining precipitation and increasing evapotranspiration, both of which will reduce recharge and possibly accelerate the decline of the groundwater level (Treidel et al. 2012). Thus, more and more people become aware of the importance of wetlands and other groundwaterdependent ecosystems (GDEs), which has resulted in the emphasis being put on a better comprehending of groundwater-ecosystem interactions in a changing climate (Kløve et al. 2011a, 2011b). Some models have been set up in the lower Heihe River Basin to simulate the groundwater flow conditions and to study the hydro-chemical characteristics. For example, a quasi-three dimensional integrated surface-groundwater flow model was constructed to predict the dynamics of groundwater level change (Zhang, 2005). Hydro-chemical characteristics have been investigated to understand the groundwater evolution, to identify the predominant geochemical processes of taking place along the horizontal groundwater flow path, and to characterize anthropogenic factors that affect the groundwater environment ( $\mathrm{Su}$ et al. 2007). From the previous studies, we can conclude that the climate change impacts on groundwater have received little attention. According to the IPCC, the global surface temperature increases linearly. Hence, climate change characterized by global warming has become one of the world's most vital environmental issues. The previous studies of rivergroundwater interactions are all under natural conditions. The objective of this study is to research the river-groundwater interactions in the two cases of evapotranspiration and no evapotranspiration in the downstream desert of the Heihe River Basin.

\section{STUDY AREA AND GEOLOGICAL SETTING}

\section{Description of the study site}

The Heihe River originates from the Qilian Mountains of Gansu province and flows into the lower Heihe River Basin of the Inner Mongolia Autonomous Region. The total length of mainstream of Heihe River is about $810 \mathrm{~km}$. At Langxin Mountain, the Heihe River is divided into two branches: 
the West River and East River, both of which flow to the north and reach East and West Lakes, respectively. The Heihe River is the only runoff flow in this area (Fig.1).

The downstream of Heihe River is located at $40^{\circ} 16^{\prime}-42^{\circ} 40^{\prime} \mathrm{N}$ and $99^{\circ} 30^{\prime}-101^{\circ} 40^{\prime} \mathrm{E}$. It covers about $3.4 \times 10^{4} \mathrm{~km}^{2}$, and the oasis is only about $0.15 \times 10^{4} \mathrm{~km}^{2}$. The lower reach of Heihe River is surrounded by low mountains to the west, north and south and by Badain Jaran Desert to the east (Fig.1). The ground surface changes slowly from south to north and from east to west, whose is about 0.0010.003 (Wu 2002). The data from the land use of the downstream of the Heihe River was found that the distribution of high evaporation areas such as desert and bare land accounted for $65.3 \%$ of the downstream region, which intensified water shortage. The study area is under the dry season for a long time from September to May and under the rainy season for a short time from June to August. The long-term climate data (1957-2001) from Ejina Meteorological Station shows that the regional annual mean evaporation, precipitation and temperature are $3599.4 \mathrm{~mm}, 38.5 \mathrm{~mm}$ and $8.1^{\circ} \mathrm{C}$, respectively. The winter minimum temperature is $-38.5^{\circ} \mathrm{C}$, while the summer maximum temperature is $43.1^{\circ} \mathrm{C}$. The day-night temperature difference can be $28-30^{\circ} \mathrm{C}$. Compared with rainfall, the higher mean annual evaporation can result in water scarcity ( $\mathrm{Su}$ et al. 2007 ).

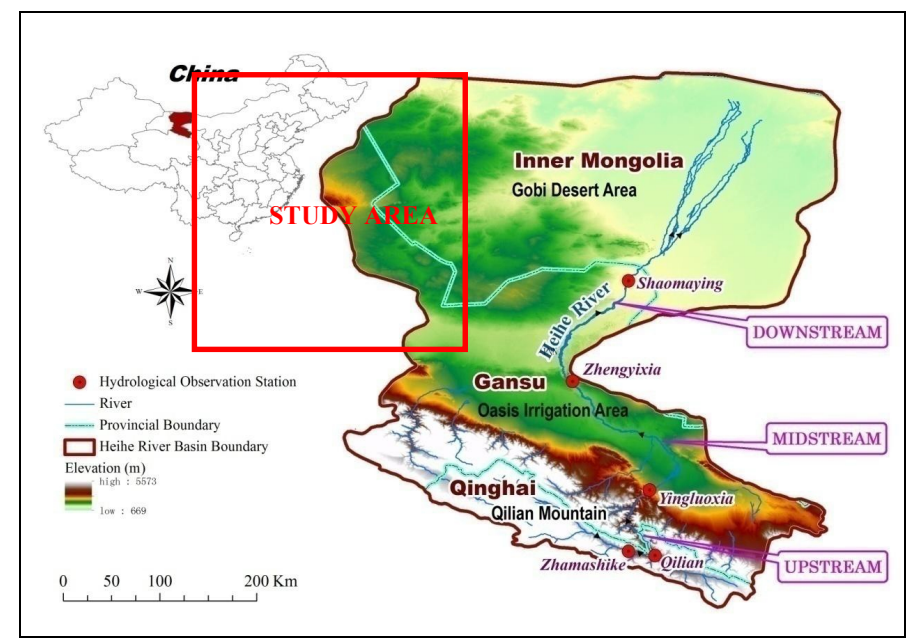

Figure 1 The location of the downstream of the Heihe River Basin

\section{Geology and hydrogeology}

Since the Cenozoic period, the basin was filled with unconsolidated Quaternary sediments, the depth of which can be about several hundred meters. It formed a united and integrated aquifer system. The southern edge of the basin is the fault of the Alashan uplift, while the northern and western edges are naked rocks of mountains. And the eastern edge is next to the hidden fault of Badain Jaran Desert. The Langxin Mountain-Mujihu uplifts control the distribution of Quaternary sediments and lithofacies characteristics. The lithofacies characteristics of the aquifer change from gravel to fine sand, from the south to the north of the basin. And the water table becomes shallow gradually. The aquifer system varied from one layer of phreatic aquifer to several layers of an unconfined-confined aquifer system (Wu 2000, Xi et al. 2010 ).

\section{DESCRIPTION OF THE GROUNDWATER MODEL}

MODFLOW-2005 is now widely used all around the world. A modular structure allows it to be easily modified to adapt the code for a particular application. It can simulate steady and non-steady flow in an irregularly shaped flow system. Flow from external stresses, such as flow to wells, areal recharge, evapotranspiration, flow to drain and flow through river beds can be simulated. And MODFLOW coupled with GIS enhances the input of the data. The three-dimension movement of groundwater is described by the partial-movement equation (McDonald and Harbaugh 1988): 
$\frac{\delta}{\delta x}\left(K_{x x} \frac{\delta h}{\delta x}\right)+\frac{\delta}{\delta y}\left(K_{y y} \frac{\delta h}{\delta y}\right)+\frac{\delta}{\delta z}\left(K_{z z} \frac{\delta h}{\delta z}\right)+W=S_{s} \frac{\delta h}{\delta t}(1)$

where $K_{x x}, K_{y y}$ and $K_{z z}$ are values of hydraulic conductivity along the x, y, and $\mathrm{z}$ coordinate axes, which are assumed to be parallel to the major axes of hydraulic conductivity; $h$ is the potentiometric head; W is a volumetric flux per unit volume representing sources and/or sinks of water, with $\mathrm{W}<$ 0.0 for flow out of the ground-water system, and $\mathrm{W}>0.0$ for flow into the system; $S_{s}$ is the specific storage of the porous material; $t$ is the time.

When combined with boundary and initial conditions, equation 1 describes transient threedimensional groundwater flow in a heterogeneous and anisotropic medium, provided the principal axes of hydraulic conductivity are aligned with the coordinate directions.

\section{MODELING METHOD}

Because of complex and variable terrain in the downstream of the Heihe River and it is a qualitative study on effect of climate change on groundwater, the study area is simplified to a rectangular region. A hydrogeological data model was constructed by 'ModelMuse' for the downstream of the Heihe River in a unified geodatabase such as DEM, initial head, horizontal conductivity and so on.

The model in this study was generalized. The finite-difference grid consists of 80 rows and 48 columns with a uniform cell size of $3 \times 3 \mathrm{~km}$ (Fig.2). The bifurcate line shows the river. In the vertical direction, the model grid was made up of five layers based on the regional conceptual model (Fig.3). The model layers from top to bottom, represents the shallow unconfined aquifer, the first confining unit, the shallow confined aquifer, the second confining unit and the deep confined aquifer, respectively. Surface elevation was taken from the previous articles. The elevation of the edge of the study area is higher than the inner area. The initial head was also taken from previous articles (Xi et al. 2010).

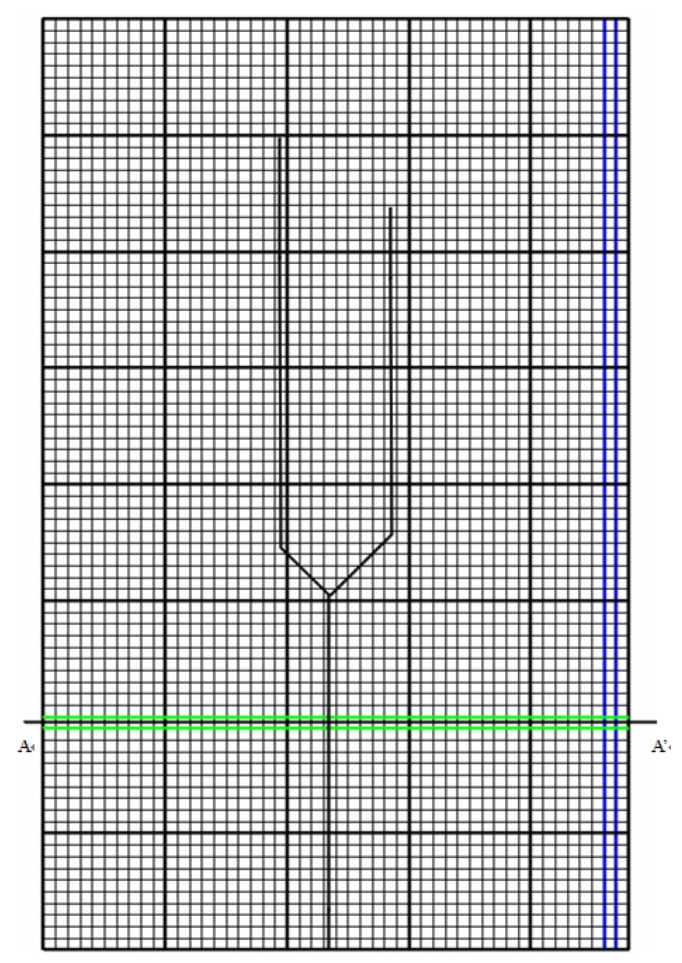

Figure 2 Model grids of the downstream of the Heihe River 


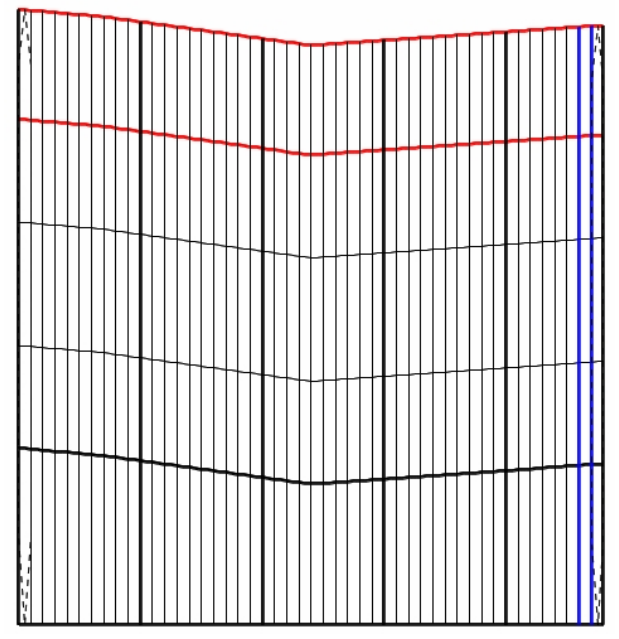

Figure 3 The model profile (A-A' in Fig.2)

The downstream Quaternary aquifer bottom consists of the Jurassic, tertiary mudstone and sandy mudstone, and local areas are Sinian marble sector rocks. The bottom boundary condition at the base of the deep confined aquifer was treated as no-flow boundary on account of the weak aquifer characteristic. The boundary condition at the top of the model is a gas-soil interface. The main recharge into the system through the top surface includes river water infiltration and precipitation. Discharge from the top border is evaporation. The lateral boundary around the aquifer system could be treated as the second type of flow boundary. The lateral recharge is relatively obvious in the eastern and southeastern Badain Jaran Desert. So it was treated as the second boundary of non-zero flow. In the western, northern and north-eastern of the study area, the Quaternary aquifer and the mountain are in connection with fault and the mountain of Jurassic clastic rocks fractured water and bedrock fissure water have a weak alimentation of plain terrain. The lateral flow is relatively small. It was regarded as the second boundary of non-zero flow, too.

The lateral boundary flow for layers 1-5 were specified flow through the Well (WEL) package of MODFLOW-2005. The Heihe River was simulated by the Streamflow Routing (SFR) package of MODFLOW-2005. The conductance of the river beds referred to the article published by Zhang et al. Evapotranspiration that was the main discharge term of the flow model was simulated using the Evapotranspiration (EVT) package of MODFLOW-2005 by assuming an extinction depth of $5 \mathrm{~m}$ across the basin.

This study chose 1999.1.1-1999.12.31 as the modeling time series. The simulation process was discrete as $365 \mathrm{~d} / \mathrm{yr}$. The every simulation time step was 1 day. So the time series were discreted as 1 year, a total of 365 steps, including 365days. In accordance with the time steps, the boundary conditions were calculated and imported into the model. This study mainly researched the influence of the evapotranspiration on river-groundwater interactions. Therefore, two different conditions were considered, the model without evapotranspiration and the model with evapotranspiration. The annual evaporation of the downstream of the Heihe River can reach about $3600 \mathrm{~mm}$, while the precipitation is less than $40 \mathrm{~mm}$. The precipitation is evaporated before recharging groundwater. So the precipitation can be neglected in this study. Only evaporation data was imported into the model. The hydraulic conductivity, specific storage, specific yield referred to the article published by $\mathrm{Wu}(\mathrm{Wu} 2002)$. Horizontal direction of the hydraulic conductivity could be regarded as isotropic, which is the $K_{x}$ equal to $K_{y}$.

The downstream desert has a long dry season. For large amount of evaporation, the groundwater table is relatively low. So after the first steady state, the model without evapotranspiration was simu- 
lated in the second time period, transient state. Model with evapotranspiration was simulated only in transient state.

\section{THE EFFECTS OF EVAPOTRANSPIRATION ON RIVER-GROUNDWATER INTERACTION}

The inflow of the river was constant. And the inflow was $6.31 \times 10^{8} \mathrm{~m}^{3} / \mathrm{yr}$. If there are not rivergroundwater interactions, the outflow of the river should be equal to the inflow. If the inflow and the outflow have difference, it shows that the river interacts with groundwater with each other. The river-groundwater interactions are shown in Fig.4.

\section{The river-groundwater interactions without evapotranspiration}

When the model was simulated without evapotranspiration, the inflow of the main Heihe River is about $6.31 \times 10^{8} \mathrm{~m}^{3} / \mathrm{yr}$ while the total outflow of the two branches was about $7.75 \times 10^{8} \mathrm{~m}^{3} / \mathrm{yr}$. So the flow that river recharged groundwater was about $1.44 \times 10^{8} \mathrm{~m}^{3} / \mathrm{yr}$. The lateral boundary flow of the groundwater model was $1.4 \times 10^{8} \mathrm{~m}^{3} / \mathrm{yr}$. The Heihe River was the main discharge.

\section{The river-groundwater interactions with evapotranspiration}

When the model was simulated with evapotranspiration, the inflow of the river was $6.31 \times 10^{8} \mathrm{~m}^{3} / \mathrm{yr}$ and the outflow was about $0.98 \times 10^{8} \mathrm{~m}^{3} / \mathrm{yr}$. So the flow that the river charged groundwater was about $5.33 \times 10^{8} \mathrm{~m}^{3} / \mathrm{yr}$. The lateral boundary flow was about $1.4 \times 10^{8} \mathrm{~m}^{3} / \mathrm{yr}$. The evapotranspiration was about $8.4 \times 10^{8} \mathrm{~m} 3 / \mathrm{yr}$. The lateral boundary flow, evapotranspiration and river leakage simulated from previous study ( $\mathrm{Wu} 2002$ ) were $1.4 \times 10^{8}, 8.625 \times 10^{8}$ and $5.3 \times 10^{8} \mathrm{~m}^{3} / \mathrm{yr}$, respectively. Although the DEM and the initial head of the study area in the model are not very accurate, all the data comes from the previous studies. The results are consistent with the actual results. It is sufficient to investigate the river-groundwater interaction characteristics.

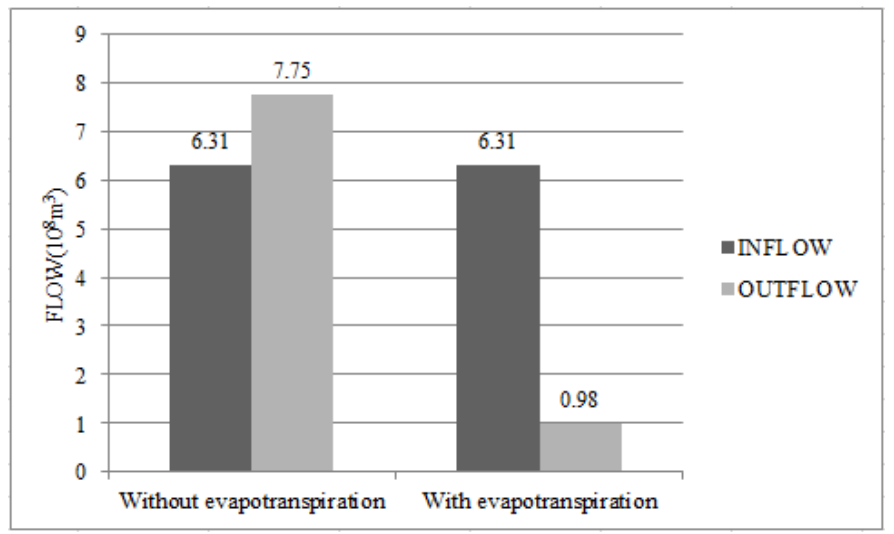

Figure 4 The results of the river-groundwater interaction. The river-groundwater interaction of no evapotranspiration and evapotranspiration was $1.44 \times 10^{8} \mathrm{~m}^{3} / \mathrm{yr}$ and $5.33 \times 10^{8} \mathrm{~m}^{3} / \mathrm{yr}$.

\section{CONCLUSION}

This study is mainly aimed to investigate the river-groundwater interaction characteristics in the downstream desert of the Heihe River. Under the action of evaporation, the outflow of the aquifer system is much larger than the inflow. The groundwater is lower than river table. The river water seeps into groundwater. Without the effect of evaporation, under the circumstances of the recharge of lateral flow, the groundwater level of the basin will rise, which make groundwater recharge the river. 


\section{ACKNOWLEDGEMENTS}

The financial support for this study is from the National Natural Science Foundation of China (No.91225301).

\section{REFERENCE}

[1] Feng Q, Xi H.Y \& Liu W.2009. The research of three-dimensional numerical simulation of groundwater-flow: taking the Ejina Basin, Northwest China as example. Sciences in Cold and Arid Regions, 03:238-248.

[2] IPCC. Climate Change 2007: The physical science basis. Cambridge: Cambridge University Press.

[3] Kløve B, Ala-Aho P \& Bertrand G, et al. 2011.Groundwater dependent ecosystems. Part I: Hydroecological status and trends. Environmental Science \& Policy, 14(7):770-781.

[4] Kløve B, Allan A \& Bertrand G, et al. 2011. Groundwater dependent ecosystems. Part II. Ecosystem services and management in Europe under risk of climate change and land use intensification[J]. Environmental Science \& Policy, 14(7):782-793.

[5] McDonald MG. \& Harbaugh AW (1988) A modular three-dimensional finite-difference ground-water flow model. U.S. Geological Survey Techniques of Water-Resources Investigations, Book 6 Chap A1, p 586

[6] Su Y.H, Feng Q \& Zhu G.F.2007. Identification and evolution of groundwater chemistry in the Ejin Sub-basin of the Heihe River, Northwest China. Pedosphere 17:331-342.

[7] Treidel, H., Martin-Bordes, J. L., \& Gurdak, J. J. (Eds.). 2011. Climate change effects on groundwater resources: a global synthesis of findings and recommendations. CRC Press.

[8] Wu X.M. 2000. Groundwater exploitation and ecological environment protection in Ejina basin of Heihe River watershed, northwestern China. Wuhan, China Univ Geosci 21:121-125 (in Chinese) .

[9] Wu X.M. 2002. The study of the Ejina basin of Heihe River watershed, northwestern China. Hydrogeology \& Engineering Geology.1:16-20 (in Chinese) .

[10] Xi H.Y, Feng Q \& Liu w. 2010. The research of groundwater flow model in Ejina Basin, Northwestern China. Environmental Earth Sciences, 60(5):953-963.

[11] Zhang G.H. 2005. Mechanism of Water Cycle, Groundwater Formation and Evolution in Northwest Heihe River Basin. Beijing: Geological Publishing House.

[12] Zhang Y, Wu Y \& Qiao M. 2002. Lysimetric experiment on the riverbed in the lower reaches of Heihe River. Arid Zone Research, 20(4): 257-260 